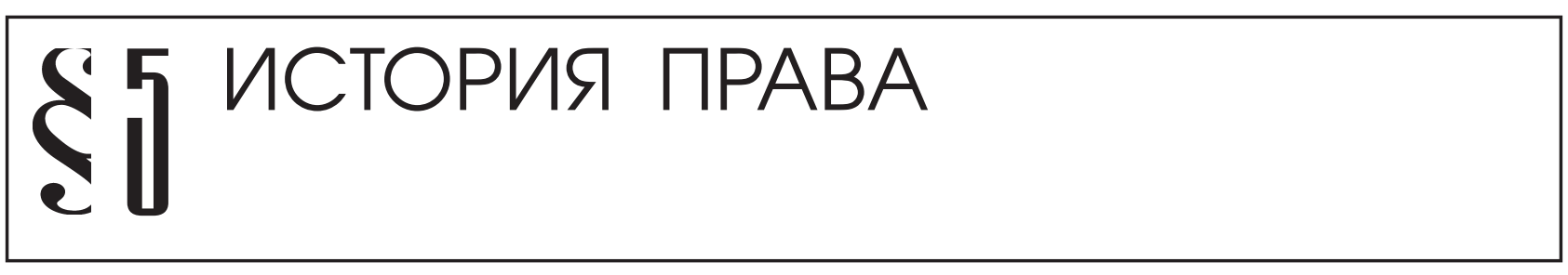

Жолобова Г.А.

\title{
ЗАКОН «О НЕКОТОРЫХ ИЗМЕНЕНИЯХ В ПОРЯДКЕ ОТКРЫТИЯ АПТЕК» 1912 г. В МЕХАНИЗМЕ ПРАВОВОГО РЕГУЛИРОВАНИЯ КОММЕРЧЕСКОЙ ФАРМАЦЕВТИЧЕСКОЙ ДЕЯТЕЛЬНОСТИ РОССИИ КОНЦА ХІХ - НАЧАЛА ХХ вВ.
}

Аннотация: B статье подняты актуальные проблемы отечественного правового регулирования деятельности аптек, направленной на получение прибыли. На основе изучения архивньх документов и анализа нормативно-правовых актов Российской империи показано формирование механизма правового регулирования в конще XIX-начале XX вв., призванного обеспечить, с одной сторонь - своевременное оказание лекарственной помощи населению, с другой - защиту частного аптечного бизнеса от разорительной конкуренщии. При этом особое внимание в этом механизме уделено закону 1912 г. «О некоторьх изменениях в порядке открытия аптек»: обоснована необходимость его принятия, проанализировано содержсание и выявлень особенности и трудности реализации. Обозначены проблемы сосуществования частновладельческих и общественньх аптек.

Review: The author of the article raises very important issues of legal regulation of Russian drugstore activities aimed at profit earning. Based on analyzed archive documents and regulatory acts of the Russian Empire, the author describes the process of formation of the mechanism of legal regulation at the end of the XIX-beginning of the XX centuries. The purpose of that legal mechanism was, on the one hand, to provide timely pharmaceutical aid to population, and, on the other hand, to protect private drugstore business from wasting competition. Special attention is paid to the Law of 1912 on Some Changes in the Procedure of Opening a Drugstore. The author proves the need in accepting this law and analyzes the contents, peculiarities and difficulties of the implementation process and outlines the main problems of co-existence of private drugstores and public drugstores. Ключевые слова: Юриспруденция, аптечная монополия, привилегия, явочный порядок, лекарства, такса, продажа, органы городского самоуправления, земство, толкование закона

Keywords: legal studies, pharmacy monopoly, privileges, formation of corporation without licensing or registration required for their validity, medicine, rate, municipal government authorities, district council, interpretation of laws.

3 акон 12 февраля 1912 г. «О некоторых изменениях в порядке открытия аптек», отвоеванный у власти либеральной общественностью и состоявший всего из четырех статей, должен был стать вехой, повлекшей существенные изменения в механизме правового регулирования коммерческих фармацевтических отношений России. В этой связи представленная вашему вниманию публикация является продолжением исследования проблем государственного обеспечения частного и общественного интересов в сфере коммерческой фармацевтической деятельности России 1881-1913 гг. ${ }^{1}$

1 Жолобова Г. А. Проблемы правового обеспечения частного и общественного интересов в сфере коммерческой
На рубеже XIX - XX вв. в условиях проявлений глубокого кризиса в отечественном фармацевтическом деле, ${ }^{2}$ успешная деятельность земских и городских органов самоуправления по оказанию более доступной лекарственной помощи населению находила все более горячую поддержку общественности. В печати неоднократно

фармацевтической деятельности в России 1881-1912 гг. // Политика и общество. 2013. №10, 2013 г. DOI: 10.7256/18128696.2013.11.10070.

${ }^{2}$ Подробнее см.: Жолобова Г. А. Правовое регулирование коммерческой фармацевтической деятельности в пореформенной России 1881-1913 гг. // Правоведение. СПб., 2012. № 1. С. $95-129$. 


\section{Политика и общество 11 (107) • 2013}

высказывались предложения о целесообразности передачи всего аптечного дела в руки городских и земских общественных управлений. Ободренные общественной поддержкой, земства все настойчивее стали выдвигать требования об отмене аптечной привилегии и предоставлении им права на свободное открытие аптек с правом вольной продажи лекарств. ${ }^{3}$ Однако в течение длительного времени эти требования не находили сочувствия в правительственных кругах, более озабоченных иными внутриполитическими проблемами, и только в 1908 году вопрос сдвинулся с мертвой точки, когда 29 мая в Государственную Думу за подписью 34-х ее членов (преимущественно октябристов и националистов) был внесен законопроект о введении явочного порядка открытия всех аптек и возможности продажи лекарств по ценам ниже установленных таксой. ${ }^{4}$

Объяснительная записка, приложенная к законодательному предложению авторами проекта и содержавшая мотивы издания нового закона, стала обличением всей российской фармацевти-

3 Российский государственный исторический архив (РГИА). Фонд 1297 (Медицинский Департамент МВД). Оп. 156. Д. 335 «По сообщенному Костромским Губернатором ходатайству Костромского Губернского Земского Собрания об отмене аптекарской монополии в виду того, что аптекари являются эксплуататорами народа», 1883 г.; РГИА. Ф. 1297. Оп. 156. Д. 375 «По представлению Воронежского Губернатора, с ходатайством Воронежского Губернского Земского Собрания, об уничтожении аптекарских привилегий», 1883 г.; РГИА. Ф. 1297. Оп. 157. Д. 150 «По представленному Курским Губернатором ходатайству Курского Губернского земского собрания о разрешении земству, буде пожелает, открывать в городах аптеки наряду с существующими. Здесь же о напечатании в «Вестнике Судебной медицины и Общественной гигиены» статьи «о предоставлении земству права учреждать аптеки», 1887 г.; РГИА. Ф. 1297. Оп. 158. Д. 11 «По представленному Курским губернатором ходатайству Курского Губернского Земского Собрания о предоставлении земству права открывать аптеки, где оно найдет это нужным», 1891 г.; РГИА. Ф. 1297. Оп. 158. Д. 14 «По представленному Полтавским губернатором ходатайству Прилуцкого уездного земского собрания об отмене аптечных привилегий», 1891 г. и др.

${ }^{4}$ Нежданов В. Высочайше утвержденный 12 февраля 1912 года закон «О некоторых изменениях в порядке открытия аптек», законодательные мотивы и постатейные разъяснения и наше аптечное законодательство. СПб., 1912. С. $9-10$. ческой системы. В этой записке, оглашенной с Думской трибуны, говорилось: «В России существует один налог, самый высокий и самый несправедливый, налог, установленный не в пользу государства, не на общественные потребности, а в пользу частных лиц, налог не на предметы роскоши, а на человеческое здоровье, на пользование от болезней. Налог этот установлен законом о монополии аптек и таксою на лекарства, согласно которой за выпускаемые из аптек лекарства берется в 10 и 20 раз более их действительной стоимости.

Многие земские и городские учреждения представляли ходатайства о разрешении открыть аптеки с удешевленною продажею лекарств, или делали попытку открыть такую продажу из своих больничных аптек, но во всех ходатайствах об этом получался отказ, а попытки удешевить лекарства продажею из больничных аптек преследовались судом.

Стремление подлежащих учреждений охранять интересы монополистов-аптекарей выходило иногда за пределы законности и здравого смысла и самые простые вещества запрещались в продаже вне аптек. Так, несмотря на то, что 17 февраля 1875 г. состоялось Высочайше утвержденное мнение Государственного Совета, которым аптечная монополия была признана крайне стеснительною для населения, и Министру Внутренних Дел, делавшему представление об усилении наказаний за внеаптечную продажу лекарств, было поручено сделать представление в Государственный Совет о совершенной отмене наказаний за продажу не сильно действующих лекарств и тем сделать покупку их доступной для населения, - Высочайшая воля эта не только осталась десятки лет без исполнения, но, напротив, при циркуляре Министерства от 7 марта 1892 г. за № 305 был приложен список лекарственных веществ, продажа которых запрещалась вне аптек и в число которых под запрет попали даже такие вещества: липовый цвет, мята, александрийский лист, шалфей, листья: брусники, земляники и черной смородины, очищенный мед, цитварное, льняное и укропное семена, можжевеловые ягоды, предохраненное от порчи свиное сало и т. п. <..>

Но даже в последнее время, несмотря на состоявшееся 22 декабря 1903 г. решение Общего 
Собрания Первого и Кассационного Департаментов Сената, которым категорически устанавливалось, что не допускается продажа вне аптек только таких препаратов, которые не могут быть отпускаемы из аптек без рецептов врачей, всеже свободная продажа остальных лекарственных предметов находится под сомнением. Дело в том, что 25 марта 1902 г. Министерство Внутренних Дел циркулярно сообщило губернаторам о прошениях владельцев аптек - подчинить более строгим условиям внеаптечную торговлю медикаментами, которая, все более и более развиваясь, делает для аптек крайне затруднительною конкуренцию с нею. Вследствие этого, по мнению Министерства, в видах облегчения для публики получения вне аптек вполне доброкачественных материалов, «должны быть поставлены пределы конкуренции с аптеками разных торговых заведений».

Этот циркуляр, имеющий силу и теперь, как будто выражает заботу об интересах публики доставлением удобства в получении доброкачественных лекарств, в действительности составляет продолжение того же покровительства аптекам и под его туманным смыслом могут возбуждаться преследования за продажу самых простых лекарственных предметов.

Какая контрибуция берется с населения в пользу владельцев монопольных аптек можно видеть из продажной ценности аптек или вернее права на владение ими. В г. Зарайске, имевшем 7.000 жителей, аптека, в которой материалов было едва ли на 500 р., продана за 15.000 р., Андроньевская аптека в Москве, с ценностью материалов, по словам ее арендатора, не более как на 7.000 р., продана за 108.000 р. Право на Ново-Триумфальную аптеку в Москве, через четыре года после ее открытия, продано за 100.000 р., а немного спустя перепродано за 120.000 р. И все эти десятки и сотни тысяч рублей выплачиваются за счет человеческого здоровья и наживаются на человеческом несчастье.

Аптечная монополия была установлена 235 лет тому назад, когда по указу Царя Алексея Михайловича в 1673 г. была учреждена первая казенная аптека, как было указано в указе, «дабы казне порухи не было». Затем Петр I разрешил открыть и частные аптеки с переносом и на них ограждения от «порухи». Но в то время такое положение для открытия аптек было необходимо; людей, знающих аптечное дело, в России не было, а чтобы вызвать для открытия аптек иностранцев, нужно было предоставить им серьезные выгоды. Другое дело теперь, когда у нас достаточно вполне образованных фармацевтов, когда монополия аптек является только вредным анахронизмом, поддерживаемым искусственными средствами.

Во многих государствах аптечная монополия давно отменена, а в других ее и совсем не было 5 , и пора покончить с нею и у нас в России, и всякий желающий, а также города, земства и общественные учреждения должны получить право открывать аптеки, где угодно и сколько угодно, и продавать лекарства на сколько угодно ниже цен установленной таксы, которая должна существовать только как максимум цен, выше которых никто брать не может». ${ }^{6}$

Обсуждение «предположения 34-х» в заседании Государственной Думы 18 января 1911 г. прошло без особых прений, и собрание народных представителей единогласно его поддержало. Правда в дальнейшем, при выработке детального законопроекта в комиссии законодательных предположений Государственной Думы, явочный порядок открытия аптек был предусмотрен только для органов земского и городского общественного управления. Проект комиссии обсуждался в заседании Государственной Думы 13 мая 1911 г. по существу. От имени правительства выступил товарищ министра внутренних дел С. Е. Крыжановский, который заявил: «Я уполномочен довести до сведения Государственной Думы, что Министерство Внутренних Дел, согласно принятому на себя обязательству, разработало уже законопроект об аптеках. Законопроект этот одобрен Медицинским Советом и будет

\footnotetext{
${ }^{5}$ В исследуемый период явочная система открытия аптек применялась в Англии, Италии, Франции, Швейцарии, Бельгии, Нидерландах, Испании, Португалии, Турции, Северо-Американских Соединенных Штатах, а концессионная система - в России, Германии, Австро-Венгрии, Швеции, Норвегии, Дании, Люксембурге, Румынии и Болгарии. Прим. Г. А. Жолобовой.

${ }^{6}$ Нежданов В. Высочайше утвержденный 12 февраля 1912 года закон «О некоторых изменениях в порядке открытия аптек», законодательные мотивы и постатейные разъяснения и наше аптечное законодательство. СПб., 1912. С. $10-12$.
} 


\section{Политика и общество 11 (107) • 2013}

внесен в Государственную Думу не позднее сентября. При таких условиях, <..> я позволю себе обратиться к Гос. Думе с просьбой, не признает ли она возможным отложить рассмотрение настоящего дела до внесения правительственного законопроекта?»7 Однако Государственная Дума 105 голосами против 101 отклонила это предложение и, признав законопроект не терпящим отлагательства, приняла его в трех обсуждениях без прений и поправок.

Затем он поступил в комиссию законодательных предположений Государственного Совета, также получив там одобрение по всем принципиальным вопросам. Комиссия нашла необходимым, дабы удержать «общественные учреждения от открытия излишних аптек», дополнить обсуждаемый законопроект правилом о том, что открытые общественными органами явочным порядком аптеки, не могут быть продаваемы, закладываемы, сдаваемы в арендное содержание или иным образом передаваемы в чье либо владение или пользование.

7 декабря 1911 г. проект «О некоторых изменениях в порядке открытия аптек» обсуждался в Государственном Совете по существу. Большинство выступлений было направлено на защиту проекта. В них, как и в Государственной Думе, обращалось внимание на серьезные затруднения, встречавшиеся на пути органов общественного самоуправления; озвучивались факты, свидетельствующие о том, что «некоторым земствам удавалось завести свои аптеки только путем перекупки таковых у частных лиц», ${ }^{8}$ не дозволялось снабжать население лекарствами по низкой цене. ${ }^{9}$

К Государственному Совету также было сделано обращение от имени правительства, содержавшее просьбу отложить принятие закона до рассмотрения уже внесенного в Думу проекта нового Фармацевтического Устава. Товарищ Министра Внутренних Дел А. Н. Харузин эту просьбу мотивировал так: «Настоящий законопроект не разрешает всего аптечного вопроса в целости, ... сохраняя ныне действующий порядок открытия

\footnotetext{
7 Там же. С. 18.

${ }^{8}$ Выступление докладчика комиссии, члена Государственного Совета С. М. Лукьянова. Там же. С. 24.

${ }_{9}^{9}$ Выступление члена Государственного Совета Н.А. Зиновьева. Там же. С. 28.
}

вольных аптек - порядок разрешительный, весьма сложный и стеснительный, - вводит новое начало, а именно: начало открытия аптек городами и земствами явочным порядком. Таким образом, сохраняя старое начало и вводя новое, этот законопроект... лишает действующее законодательство стройности». ${ }^{10}$

Интересен тот факт, что против отсрочки принятия закона возразил даже бывший товарищ Министра Внутренних Дел, член Государственного Совета Н. А. Зиновьев. Выступая в заседании Государственного Совета, он, в частности, говорил: «Аптечный вопрос - это один из самых несчастных вопросов в России. ... Где являлся всегда тормоз к разрешению аптечного вопроса в том виде, как об этом 30 лет хлопочут и земства и города? К сожалению, он всегда встречался именно в Министерстве Внутренних Дел, т. е. именно во врачебной части... И потом, какое же отношение имеет Фармацевтический Устав к настоящему делу? ...тут другое дело - дело чисто коммерческое: уничтожить те привилегии, то крепостное право, которое тяготеет над населением, которое обязано покупать лекарства по дорогой цене, которая постоянно возвышается и ставит, действительно, неимущее население часто в совершенно невозможное положение. Единственное средство - это разрубить тот Гордиев узел, развязывание которого тянется уже 30 лет. Поверьте, что если мы отложим рассмотрение закона, то еще 5-6 лет, будет это продолжаться, а через 6 лет будут поставлены для этого новые преграды». ${ }^{11}$ Подобное обличение роли Министерства Внутренних Дел в «решении аптечной проблемы» и пугающе пророческие перспективы из его уст звучали особенно авторитетно.

Проект Государственной Думы с внесенными в него Государственным Советом изменениями был одобрен межпалатной согласительной комиссией, а затем единогласно принят Государственной Думой. В этой же редакции 12 февраля 1912 года одобренный Государственным Советом и Государственною Думою закон «О некоторых изменениях в порядке открытия аптек» получил Высочайшее утверждение.

Таким образом, с момента внесения в Государственную Думу законодательной инициативы

\footnotetext{
10 Там же. С. 27.

${ }^{11}$ Там же. С. $28-29$.
} 
понадобилось еще целых четыре года, чтобы небольшой (состоящий всего из четырех статей), но очень важный документ, стал законом. Он предоставил право земским и городским общественным управлениям учреждать и содержать аптеки без всякого согласия других собственников аптек и дозволения губернских властей, руководствуясь лишь постановлением земских собраний или городских дум. В результате вводился явочный порядок учреждения таких аптек с обязательством земских и городских управ не позже, чем за месяц до открытия аптек сообщать о предстоящем событии местному врачебному управлению. При этом аптеки, открытые и находящиеся на содержании земских и городских органов самоуправления, не могли продаваться, сдаваться в аренду или иным способом передаваться в чьелибо владение или пользование. ${ }^{12}$

Казалось бы, органы земского и городского самоуправления должны были торжествовать свою победу?! Но, не тут то было! Теперь нужно было не только изыскивать финансовые возможности, но и отвоевывать свое «законное право» на открытие аптек, преодолевая сопротивление местных аптекарей и чиновников. В руках же министерства оставался такой рычаг, как ведомственные циркуляры и инструкции, а в руках правительства - разъяснения Сената, которые позволяли найти «законные лазейки» для обхода неугодного закона.

Уже в рапорте «О разъяснении некоторых вопросов по применению закона 12 Февраля 1912 года...» № 1166, направленном в Правительствующий Сенат 18 ноября 1912 г. за подписью Товарища Министра Внутренних Дел А. Харузина и Главного Врачебного Инспектора Малиновского, не скрывалось негодование по поводу принятого закона: «Не будучи обсужден, предварительно, с участием заинтересованного ведомства, т. е. Министерства Внутренних Дел и проведенный по инициативе Государственной Думы, закон этот не является органически связанным ни с действующим законом, ни с тем проектом Фармацевтического

\footnotetext{
12 Полное собрание законов Российской империи. Собрание третье (ПСЗ - ІІІ). Т. ХХХІІ. № 36527. Февраля 121912 г. Высочайше утвержденный одобренный Государственным Советом и Государственною Думою закон «О некоторых изменениях в порядке открытия аптек». С. 104.
}

Устава, который был внесен названным Министерством в Думу, по одобрении Советом Министров. Новый закон, состоящий всего из 4-х статей, вносит, однако, совершенно новые начала в дело учреждения в России аптек: в разрез с системою разрешительного порядка аптек, державшеюся у нас со времени ИМПЕРАТОРА Петра Великого, устанавливается явочный порядок открытия аптек, но исключительно для земских и городских общественных управлений, которые, таким образом, как это прямо выражено в статье 1-й нового закона, могут «учреждать и содержать аптеки без соблюдения правил о порядке их открытия, изложенных в статьях 353 - 356 Устава Врачебного (Св. Зак.. т. XIII., изд. 1905 г.)».

Уже первоначальное применение означенного нового закона вызвало ряд сомнений в отношении каждого из его статей $<\ldots>$ ». ${ }^{13}$

Далее в рапорте были сформулированы проблемы соотнесения норм вновь принятого нормативного акта с действующим законодательством, выявившиеся на практике в ходе реализации закона 1912 г. на местах и требующие специального разъяснения Правительствующего Сената. В заключении рапорта предлагалось их решение. Сенату также сообщалось, что Министерство Внутренних Дел уже разъяснило два вопроса в циркулярном распоряжении по Управлению Главного Врачебного Инспектора, разосланном на имя Губернаторов и Градоначальников от 20 Апреля 1912 года за № 401. В этом Циркуляре значилось, что «на основании упомянутого закона, общественные установления (городские и земские) имеют право открывать собственные нормальные вольные аптеки в любом количестве - независимо от числа уже имеющихся в данном пункте аптек - и произвольно выбирая места для своих аптек. Для осуществления этого права земским и городским управлениям нет надобности возбуждать пред кем бы то ни было какое либо ходатайство, так как помянутый закон признает достаточным для этого выполнение лишь двух условий: 1) соответствующего постановления земского собрания и городской думы и 2) сообщения земскими и городскими управами не позже, как за месяц до

${ }^{13}$ РГИА. Ф. 1298 (Управление Главного Врачебного Инспектора МВД). Оп. 1. Д. 1889. Л. 62. 


\section{Политика и общество 11 (107) • 2013}

открытия аптек, местному врачебному управлению о предстоящем их открытии. <..> К сему считаю необходимым присовокупить, что новый закон изменяет порядок открытия аптек исключительно для городских и земских учреждений и что он не отменяет ни в чем действующего закона, касающегося организации надзора за аптеками и ответственности за ведение в аптеках дела, а потому открытые явочным порядком городские и земские вольные аптеки будут подлежать ревизии местной врачебной инспекции на общем основании, а управляющие этими аптеками и служащие в них фармацевты за всякие упущения по ведению аптечного дела подлежат ответственности на общем же основании. Подписал: Министр Внутренних Дел, Сенатор Макаров. Скрепил: Главный Врачебный Инспектор Малиновский». ${ }^{14}$

Далее в Рапорте МВД формулировалась позиция министерства по всем поставленным «сомнительным вопросам» «общего применения нового закона»:

1. По вопросу, распространяется ли закон 12 февраля 1912 г. и на открытие сельских аптек, а также отделений аптек нормальных, открытых явочным порядком или же ранее учрежденных в разрешительном порядке, министерство высказалось отрицательно, т. к. «распространять действие нового закона и на аптеки сельские или на аптечные отделения значило бы чрезвычайно облегчить повсеместное учреждение этого типа аптек, который, по справедливости, должен считаться лишь, так сказать, суррогатом аптеки, т. е. крайне несовершенным видом аптечного учреждения, далеко не в полной мере удовлетворяющей запросы на врачебные средства...». ${ }^{15}$

2. Вопрос «имеют ли право Губернаторы и Градоначальники, на общих основаниях, т. е. на основании соответствующих статей городового и земского положений ${ }^{16}$, опротестовывать постановления земских собраний и городских дум,

\footnotetext{
${ }^{14}$ Там же. Л. 12 - 12 об.

15 Там же. Л. 64.

16 По Положению о губернских и уездных земских учреждениях 1890 г. (ст. ст. 86, 87,) и по Городовому Положению 1892 г. (ст. ст. 82, 83), местное губернское начальство было уполномочено приостанавливать все те постановления органов местного общественного управления, которые не относятся к категории постановлений, утверждаемых местною или центральною властью.
}

коими разрешено открыть новые аптеки по о3наченному закону 12 -го Февраля сего года» ${ }^{17}$ министерство предлагало разрешить положительно, «т. е. в смысле признания за местным начальством права препятствовать осуществлению предположений земских и городских общественных управлений по открытию аптек». ${ }^{18}$ Доводы к тому были приведены те же, что и в период «неприкосновенности аптечной монополии»: «Опасность же применения нового закона кроется в том, что при неограниченной ничем возможности открывать аптеки явочным порядком, т. е. без всякой предварительной оценки со стороны действительной надобности в учреждении новой аптеки и при допускаемом новым законом произволе для городов и земств в выборе места для новой аптеки, новые явочные аптеки могут встретиться с аптеками, существовавшими ранее, но недостаточно окрепшими, и может развиться между теми и другими крайне вредная конкуренция ... опасная сторона свободной конкуренции между аптеками заключается в том, что содержатели аптек, недобросовестные или склонные стать на путь понижения качества своих препаратов, ради борьбы за существование, будут отпускать населению врачебные средства плохого качества, а это может обусловить трудно учитываемый, но систематический вред интересам народного здравия. Единственными гарантиями от таких тяжелых последствий могут быть только самый строгий фактический надзор за аптеками и самое суровое применение репрессий уголовного закона к нарушителям аптечного порядка. Между тем современное положение таково, что не приходится вовсе рассчитывать не только на систематический контроль аптек, но даже и на сколько ни будь действительный фактический надзор за ними. Местные врачебные управления недостаточно организованы для осуществления такого надзора, не имеют они и соответствующего личного состава, свободного для фактического надзора во всякое время за аптеками, ни достаточных прогонных кредитов для поездок, ни, наконец, такого лабораторного устройства, чтобы анализировать препараты, выбираемые при ревизии аптек. С другой стороны, карательные ста-

\footnotetext{
${ }^{17}$ РГИА. Ф. 1298. Оп. 1. Д. 1889. Л. 63 об.

${ }^{18}$ Там же. Л. 64 об.
} 
тьи уголовного закона страдают значительной неполнотой, а потому даже и тщательное применение их во всех случаях далеко не гарантирует аптечное дело от возможных в нем неустройств, недостатков и злоупотреблений...». ${ }^{19}$

Таким образом, Министерство Внутренних Дел фактически расписалось в собственном бессилии, но вместо должной организации надзора за здравоохранением решило действовать привычными методами - путем усиления административного нажима и запретительными мерами.

3. Третий вопрос «имеют ли право воспользоваться этим законом для открытия аптек в одном и том же городе и губернское земство и городское управление и ближайшее уездное земство, которое именуется по названию данного города», ${ }^{20}$ Министерство Внутренних Дел намеревалось разрешить отрицательно, используя ограничительное толкование закона. Фактически предлагалось распределить исключительные преимущества в создании аптек между общественными установлениями на тех иерархических началах, которые были установлены незадолго до введения в действие закона 1912 г. - Циркуляром МВД от 17 января 1912 г. № 59:21 во всех городах исключительное

${ }^{19}$ Там же. Л. 64 об - 65 об.

${ }^{20}$ Там же. Л. 63 об.

${ }^{21}$ Циркуляром МВД от 17 января 1910 г. № 59 вносились изменения в Правила от 25 мая 1873 г. об открытии аптек в части распределения очереди между кандидатами: «...При выдаче разрешений на открытие допускаемых к учреждению аптек преимущество отдается общественным установлениям, причем во всех городах предпочтение получают городские общественные управления, а затем ... в губернских городах - губернские земства, а в уездных городах и во всех других пунктах по уезду - уездные земства. После всех вышеозначенных общественных установлений преимущество отдается фармацевтам, на следующих основаниях...»: 1) имеющим наибольший стаж безупречного управления нормальной аптекой; 2) наибольший стаж службы в сельской аптеке в звании не ниже провизора... Подробнее см.: Сборник законоположений и правительственных постановлений для фармацевтов, частных и общественных аптек, аптекарских магазинов, фабрик и лабораторий фармацевтических препаратов, заведений искусственных минеральных вод и прочих предприятий фармацевтической промышленности. Сост. В. Л. Левентон. 2-е изд. СПб., 1913. С. 37 - 39; Нежданов В. Высочайше утвержденный 12 февраля 1912 года закон «О некоторых изменениях в порядке открытия аптек», законодательные преимущество получали городские общественные управления, а затем - в губернских городах - губернские земства, а в уездных городах и во всех других пунктах по уезду - уездные земства.

4. На городские общественные органы тех пунктов, где введено лишь «упрощенное городское управление», действие закона 1912 г. распространять не предполагалось.

Почти через год после получения рапорта, 9 октября 1913 года был подготовлен Указ Его Императорского Величества, Самодержца Всероссийского, из Правительствующего Сената, Министру Внутренних Дел, в котором по «возбужденным Министром Внутренних Дел общим вопросам» были сделаны следующие заключения.

По вопросу о том, имеют ли право Губернаторы и Градоначальники, на общих основаниях, опротестовывать постановления городских дум и земских собраний о разрешении открывать новые аптеки по закону 12 Февраля 1912 года, Сенат ответил положительно, поддержав позицию МВД. ${ }^{22}$ По вопросу о том, имеют ли право открывать аптеки по закону 12 Февраля 1912 городские общественные установления тех городских поселений, в коих введено лишь упрощенное общественное управление, также было утверждено представление министерства и дано отрицательное заключение. ${ }^{23}$ Указом в точности повторялась позиция министерства и о необходимости учета аптек открытых явочным порядком (но не решений об их открытии) при учреждении новых частных аптек. Это важно было впредь иметь в виду, т. к. на практике после принятия закона 1912 г. открытие частных вольных аптек осложнялось необходимостью предварительного выяснения у органов местного самоуправления вопроса об отсутствии у них желания на подобное открытие. ${ }^{24}$

мотивы и постатейные разъяснения и наше аптечное законодательство. СПб., 1912. С. 55 - 58.

22 РГИА. Ф. 1298. Оп. 1. Д. 1889. Л. 111 - 111 об.

${ }^{23}$ Там же. Л. 111 об. -112.

24 Ярким примером тому служат материалы об открытии в 1912 г. второй аптеки в г. Старый Оскол Государственного архива Курской области (ГАКО). Ф. 33 (Курское губернское правление). Оп. 2. Д. 5431. Л. 66 - 70 См.: Коротеева Н. Н. Аптечное дело в Курской губернии в середине XIX - начале XX в. Дисс...к.и.н. Курск, 2004. С. 56 - 57. 


\section{Политика и общество 11 (107) • 2013}

Цель ст. 3 закона об обязанности земских и городских аптек не позже, как за месяц до своего открытия сообщать о том местному врачебному управлению состояла, согласно Сенатскому разъяснению, в том, чтобы «дать местному врачебному управлению или местным правительственным врачам (уездному и городовому) возможность осмотреть подлежащую открытию в явочном порядке аптеку, - дабы, если при осмотре будут найдены какие либо несоответствия аптеки, по устройству или снабжению, требованиям закона, врачебное управление могло сообщить о том подлежащей городской или земской управе для принятия ею надлежащих мер к устранению указанных недостатков». ${ }^{25}$

Статья 4 закона по вопросу: «подлежат ли ограничениям в отношении продажи, сдачи в арендное содержание или передачи иным образом в чье либо владение или пользование аптеки, которые до издания означенного закона, были открыты на общем основании земскими и городскими общественными управлениями, как равно и аптеки, которые впоследствии могут быть приобретены ими каким либо способом?» получила разъяснение - нет, не подлежат, «и, следовательно, могут быть продаваемы и сдаваемы в аренду или, передаваемы в чье либо владение и пользование». ${ }^{26}$

Однако другие вопросы, в том числе касающиеся явочного порядка учреждения сельских аптек, не нашли отражения в данном Указе, что существенно затрудняло реализацию закона 1912 г. на местах.

Новый закон 1912 года вызвал настоящую панику среди владельцев аптек. С мест стали поступать жалобы на то, что земства собираются открывать или уже открыли свои аптеки рядом с уже существующими частными аптеками. ${ }^{27}$ Весь-

${ }^{25}$ Там же. Л. 113 об. -114.

${ }^{26}$ Там же. Л. 114 - 114 об.

27 Весьма показательным в этом отношении явилось прошение, направленное 15 марта 1913 г. Главному Врачебному Инспектору содержателем Чембарской вольной аптеки в Пензенской губернии, провизора Г. Л. Гуревича. РГИА. Ф. 1298. Оп. 1. Д. 1889. Л. 85 - 85 об.; Там же. Л. 81 - 81 об. (Отношение Градоначальника Ростова-на-Дону Министру Внутренних Дел от 2 марта 1913 г. о постановлении Ростовской-на-Дону Городской Думы об открытии аптеки в самом центре города рядом с другими аптеками); Там же. ма показательным в этом отношении явилось прошение, направленное 15 марта 1913 г. Главному Врачебному Инспектору содержателем Чембарской вольной аптеки в Пензенской губернии, провизора Г. Л. Гуревича: «Состоя содержателем Чембарской вольной аптеки, я уже в продолжение нескольких месяцев подвергаюсь травле и рискую потерять все свое маленькое состояние, добытое мною неимоверным тяжелым трудом в продолжение всей моей двадцатипятилетней фармацевтической деятельности. Дело в следующем. Нынешней осенью Чембарское уездное земское собрание решило открыть земством вторую в городе аптеку с вольным отпуском согласно закона от 12 Февраля прошлого 1912 года. Стали приискивать дом под эту новую аптеку и решили, что лучшего дома нет, как тот, где я помещаюсь со своей аптекой; мотив тот, что это место уже насижено мною, что весь безграмотный люд уезда уже знает, что тут помещается вольная аптека, и земству без хлопот сразу удастся выжить старого конкурента и на пепелище его благосостояния создать земское счастье. Для этого земство стало предлагать моему домохозяину такую небывалую цену за его дом, что моему домохозяину стал выгодно мне уплатить неустойку по контракту а земству продать свой дом под аптеку, а меня выселить и окончательно разорить, ибо не земству пришлось бы открывать новую вторую аптеку в ничтожном захолустном маленьком непромышленном уездном городишке с 6 тысячами жителей, - а мне, и следовательно, расчет был правильный, чтобы меня в один прием разорить.

На такие поползновения земства я поехал жаловаться в Пензу Господину Врачебному Ин-

Л. 89 - 90, 171 - 171 об. (Жалоба содержателей аптек г. Мариуполя в 1-й Департамент Правительствующего Сената от 5 апреля 1913 г. об открытии аптеки Мариупольской Городской Управой «в районе остальных аптек», содержавшая ходатайство об отмене Циркуляра МВД от 20 апреля 1912 г. и запрете открывать общественные аптеки вблизи существующих аптек», 1 марта 1915 г. была признана Сенатом «не заслуживающей уважения»); Там же. Л. 70 - 71. (Отношение Калужского Губернатора в Управление Главного Врачебного Инспектора от 21 декабря 1912 г. о постановлении Уездного Земского Собрания «существующую в с. Ново-Александровском вольную нормальную аптеку закрыть и вместо ее открыть в с. Спас-Деменском сельскую аптеку», несмотря на то, что там уже несколько лет существует частная сельская аптека) и др. 
спектору и Господину Губернатору. Они мне ответили, что земство может теперь делать все это согласно закона от 12 Февраля 1912 года.

Тогда я обратился к юристу, который мне разъяснил, что земство не может меня сдвинуть с места, благодаря смыслу моего контракта, о чем я нотариально написал земству, и оно на некоторое время успокоилось и отстало от меня.

Для ясности дальнейшего я должен упомянуть, что у моего домохозяина есть один двор, на котором помещаются два каменных двухэтажных дома, выходящих на улицу так, что их разделяют только одни ворота шириною около 2 саженей. Я занимаю нижний этаж одного дома и при заключении контракта упомянул, что в следующем доме моего домохозяина не может быть отдано ни одно помещение под торговлю аптекарскими товарами. Не смотря на такое условие, земство затевает следующую комбинацию: купить тот дом, где я помещаюсь с аптекой, а второй дом моего домохозяина пока взять в аренду и в его нижнем этаже, сыром и гнилом полуразрушенном здании, поместить свою земскую вторую вольную аптеку в двух саженях от моей аптеки, а когда через пять лет кончится мой контракт, перейти в мое помещение. Конечно умысел тут другой. Земство уверено, что они, как организованное общество, сильнее меня и вот они за 2-3 месяца меня разорят, и тогда я сам уйду, а им останется свободное поле битвы, ...а потому считая, что хотя закон от 12 Февраля 1912 года и дал право земствам повсеместно вне очереди открывать вольные аптеки, но они все таки должны соблюдать законы и что они не могут, в буквальном смысле, стать на голову старой аптеки, что им не дано право нарушать контракт мой по торговле медикаментами в том помещении, которое находится под моим запретом, и, наконец, при открытии, хотя бы и земской аптеки, должны быть соблюдены санитарно-гигиенические условия и нельзя допустить, чтобы земство открывало аптеку в сырой и гнилой яме, лишь бы выжить старого аптекаря.

Обо всем этом я вынужден доложить Вам и всепокорнейше просить Ваше Превосходительство сделать надлежащее распоряжение о недопущении разорить меня...». ${ }^{28}$ В ответ на запрос

${ }^{28}$ РГИА. Ф. 1298. Оп. 1. Д. 1889. Л. 85 - 85 об.
Главного Врачебного Инспектора по данной жалобе Пензенский Губернатор в мае 1913 г. докладывал: «Чембарская Уездная Земская Управа сообщила, что действительно в этом году по постановлению Земского Собрания предполагается открыть в г. Чембаре вольную аптеку согласно закона 12 Февраля 1912 года явочным порядком, но что дом под аптеку Управою еще не намечен и о найме такового будет своевременно сообщено». ${ }^{29}$

Реакция местных властей на открытие общественных аптек не была однозначной. Одни губернаторы поддерживали жалобы, направляемые в 1-й Департамент Правительствующего Сената содержателями частных аптек, «о подрыве» их учреждений земствами: г. Глухова Черниговской губернии, ${ }^{30}$ г. Староконстантинов Волынской губернии, ${ }^{31}$ г. Саранска Пензенской губернии, ${ }^{32}$ г. Миргорода Полтавской губернии, ${ }^{33}$ губернского города Пензенской губернии ${ }^{34}$ и др. Иные главы местной администрации, приветствуя открытие нормальных аптек городскими и земскими общественными управлениями, высказывали пожелания о более планомерном распределении аптек и добивались переноса открываемых общественных аптек в другие места, где в них действительно чувствовалась необходимость. К таковым, например, относились Эстляндский губернатор, высказавшийся против открытия в самом центре г. Ревеля городским общественным управлением 4-й нормальной аптеки (9-й из существующих в городе), между тем как «вторая часть города, с ежегодно прирастающим населением и дачною местностью, вовсе не имеет постоянной аптеки»; ${ }^{35}$ Владимирский губернатор, выразивший свои замечания по поводу открытия аптеки в центре г. Мурома; ${ }^{36}$ Кутаисский губернатор - в центре губернского города; ${ }^{37}$ и гу-

\footnotetext{
${ }^{29}$ Там же. Л. 94 - 94 об.

${ }^{30}$ Там же. Л. 103.

${ }^{31}$ Там же. Л. 120.

32 Там же. Л. 122.

${ }^{33}$ Там же. Л. 123.

${ }^{34}$ Там же. Л. 102.

${ }^{35}$ РГИА. Ф. 1298. Оп. 1. Д. 1797. Л. 23.

${ }^{36}$ Там же. Л. 22.

${ }^{37}$ РГИА. Ф. 1298. Оп. 1. Д. 1889. Л. 109.
} 


\section{Политика и общество 11 (107) • 2013}

бернатор Семипалатинской области - по вопросу выбора места в г. Павлодаре. При этом последний не скрывал, что по его сведениям, обороты старой аптеки после открытия новой не только не снизились, но даже и возросли. ${ }^{38}$ Наиболее же прогрессивные представители губернской администрации, в ответ на поданные жалобы частных аптекарей в своих отзывах указывали на то, что учреждение новых общественных аптек, хотя и «отзывается вредно на конкуренции прочих», но, не преследуя чисто коммерческих целей, приносит несомненную пользу населению, давая возможность дешевле приобретать медикаменты. В их ряду были Волынский губернатор, поддержавший создание земской аптеки в г. Житомире, ${ }^{39}$ Пермский и Минский губернаторы - в губернских городах, ${ }^{40}$ Смоленский губернатор - в г. Сычевки ${ }^{41}$ и др.

На очередном Российском фармацевтическом съезде в мае 1913 г. отмечалось, что закон 1912 г. значительно усилил конкурентную борьбу в сфере аптечного дела и что получившие привилегии конкуренты открыто делают ставку на разорение частных аптек, а ведь именно частные аптеки в настоящее время играют основную роль в деле лекарственного снабжения населения. Большинство участников Российского фармацевтического съезда выступили за отмену закона 1912 года. В целях сохранения «основного звена лекарственного снабжения» - частной аптеки - делегаты съезда обратились к земствам и городским думам с просьбой не использовать привилегии, вытекавшие из нового закона об открытии аптек. Вняли ли земства призывам делегатов Российского фармацевтического съезда или на то были другие причины (финансовые трудности и административные препоны местных властей), но сеть общественных аптек развивалась не слишком быстро. В 1916 г. в стране имелась всего 201 земская аптека, ${ }^{42}$ т. е. за 6 лет на всей территории России органами общественного самоуправления было учреждено всего 35 новых аптек.

\footnotetext{
${ }^{38}$ Там же. Л. 152.

${ }^{39}$ Там же. Л. 110.

${ }^{40}$ Там же. Л. 130, 148.

${ }^{41}$ Там же. Л. 124.

${ }^{42}$ Сало В. М. История фармации в России. М., 2007. С. 211.
}

Лишь по прошествии трех лет после принятия закона 1912 г., в условиях начавшейся I Мировой войны, когда все недостатки фармацевтического дела в России проявятся наиболее остро и начнет надвигаться «медикаментозный голод», 15 декабря 1914 г. нерешенные вопросы, поднятые в рапорте МВД от 18 ноября 1912 г. № 1166 будут разрешены Сенатом в наиболее благожелательном русле, противоречащем официальной позиции МВД.

В частности, по вопросу открытия сельских аптек и аптечных отделений явочным порядком будет дано такое разъяснение. «Ст. 1 закона 12 Февраля 1912 года предоставляет земским и городским общественным управлениям учреждать и содержать аптеки без соблюдения правил о порядке их открытия, изложенных в ст. ст. 353 - 356 Уст. Врачебн., причем не сделано никаких изъятий ни в отношении открытия сельских аптек, учреждение и устройство коих определяется правилами, изданными 6 Ноября 1881 года Министром Внутренних Дел в силу предоставленного емУ ВЫСОЧАЙШЕЮ властью полномочия, ни в отношении аптечных отделений, учреждаемых в порядке § 2 правил об открытии аптек, изданных 25 Мая 1873 года Министром Внутренних Дел. ...Если засим Министр Внутренних Дел нашел возможным при издании правил 6 Ноября 1881 года, освободить учреждаемые на основании этих правил сельские аптеки от исполнения некоторых требований, предъявляемых Уставом Врачебным в отношении управления, устройства и снабжения аптек, то от Министра зависит в настоящее время внести соответствующие изменения в эти правила, коль скоро он признает действующие на основании их аптеки «крайне несовершенным типом аптечного учреждения»; при чем такие изменения, по распубликовании соответствующих постановлений в надлежащем порядке, должны получить обязательное значение для всех вообще содержателей сельских аптек, в том числе и для земских общественных управлении... В виду изложенных соображений... Первое Общее Собрание Правительствующего Сената находит, что п. 1 закона 1912 года распространяется на открытие земскими и городскими общественными управлениями как сельских аптек, так и аптечных отделений содержимых ими нормальных 
аптек, а потому ОПРЕДЕЛЯЕТ: разъяснить настоящий вопрос в положительном смысле». ${ }^{43}$

По вопросу о том, «имеют ли право воспользоваться законом 12 Февраля 1912 года для открытия аптек в одном и том же городе и губернское земство и городское управление и уездное земство, которое именуется по названию данного города» Правительствующий Сенат, в отличие от МВД, создавшего иерархию исключительных полномочий, разъяснит данный вопрос в соответствии с буквальным смыслом ст. 2 закона 1912 г., т. е. положительно. ${ }^{44}$

Аптечное дело и аптечное законодательство просуществует в кризисном состоянии до революционных событий 1917 г. В этой связи заключительная часть выступления бывшего товарища Министра Внутренних Дел Н. А. Зиновьева в Государственном Совете по законопроекту «О некоторых изменениях в порядке открытия аптек» 1912 г. оказалась поистине пророческой. Как известно, именно по прошествии 6 лет падет самодержавие, а в 1918 году «гордиев узел» аптечных проблем будет разрублен советской властью: Декретом Совнаркома от 28 декабря все аптеки национализируются, а внеаптечная торговля лекарственными средствами будет запрещена.

\section{Библиография:}

1. Российский государственный исторический архив (РГИА). Фонд 1297 (Медицинский Департамент МВД). ОП. 156. Д. 335 «По сообщенному Костромским Губернатором ходатайству Костромского Губернского Земского Собрания об отмене аптекарской монополии в виду того, что аптекари являются эксплуататорами народа», 1883 г.

2. РГИА. Ф. 1297. Оп. 157. Д. 150 «По представленному Курским Губернатором ходатайству Курского Губернского земского собрания о разрешении земству, буде пожелает, открывать в городах аптеки наряду с существующими. Здесь же о напечатании в «Вестнике Судебной медицины и Общественной гигие-

${ }^{43}$ РГИА. Ф. 1298. Оп. 1. Д. 1889. Л. $156-158$.

${ }^{44}$ Там же. Л. 158 - 159. ны» статьи «о предоставлении земству права учреждать аптеки», 1887 г.

3. РГИА. Ф. 1297. Оп. 158. Д. 11 «По представленному Курским губернатором ходатайству Курского Губернского Земского Собрания о предоставлении земству права открывать аптеки, где оно найдет это нужным», 1891 г.

4. РГИА. Ф. 1297. Оп. 158. Д. 14 «По представленному Полтавским губернатором ходатайству Прилуцкого уездного земского собрания об отмене аптечных привилегий», 1891 г.

5. РГИА. Ф. 1297. Оп. 156. Д. 375 «По представлению Воронежского Губернатора, с ходатайством Воронежского Губернского Земского Собрания, об уничтожении аптекарских привилегий», 1883 г.

6. РГИА. Ф. 1298 (Управление Главного Врачебного Инспектора МВД). Оп. 1. Д. 1797.

7. РГИА. Ф. 1298. Оп. 1. Д. 1889.

8. Полное собрание законов Российской империи. Собрание третье (ПС3 - III). Т. XXXII. № 36527. Февраля 121912 г. Высочайше утвержденный одобренный Государственным Советом и Государственною Думою закон «О некоторых изменениях в порядке открытия аптек». С. 104.

9. Жолобова Г. А. Правовое регулирование коммерческой фармацевтической деятельности в пореформенной России 1881-1913 гг. // Правоведение. СПб., 2012. № 1. С. 95 - 129.

10. Коротеева Н. Н.Аптечное дело в Курской губернии в середине XIX - начале XX в. Дисс... к.и.н. Курск, 2004.

11. Нежданов В. Высочайше утвержденный 12 февраля 1912 года закон «О некоторых изменениях в порядке открытия аптек», законодательные мотивы и постатейные разъяснения и наше аптечное законодательство. СПб., 1912.

12. Сало В. М. История фармации в России. М., 2007. С. 211.

13. Сборник законоположений и правительственных постановлений для фармацевтов, частных и общественных аптек, аптекарских магазинов, фабрик и лабораторий фармацевтических препаратов, заведений искусственных минеральных вод и прочих предприятий фармацевтической промышленности. Сост. В. Л. Левентон. 2-е изд. СПб., 1913. 
DOI: $10.7256 / 1812-8696.2013 .11 .7707$

При цитировании этой статьи сноска на dоі обязательна

\section{Политика и общество 11 (107) • 2013}

\section{References (transliteration):}

1. Zholobova G. A. Pravovoe regulirovanie kommercheskoi farmatsevticheskoi deyatel'nosti v poreformennoi Rossii 1881-1913 gg. // Pravovedenie. SPb., 2012. № 1. S. $95-129$.

2. Koroteeva N. N.Aptechnoe delo v Kurskoi gubernii v seredine XIX - nachale XX v. Diss...k.i.n. Kursk, 2004.
3. Nezhdanov V. Vysochaishe utverzhdennyi 12 fevralya 1912 goda zakon «O nekotorykh izmeneniyakh $\mathrm{v}$ poryadke otkrytiya aptek», zakonodatel'nye motivy i postateinye raz'yasneniya i nashe aptechnoe zakonodatel'stvo. SPb., 1912.

4. Salo V. M. Istoriya farmatsii v Rossii. M., 2007. S. 211. 